\title{
VYUŽITIE POTENCIÁLU ROZPTÝLENÉHO OSÍDLENIA V CESTOVNOM RUCHU V NOVOBANSKEJ ŠTÁLOVEJ OBLASTI
}

\section{UTILIZATION OF THE DISPERSED SETTLEMENT POTENTIAL IN TOURISM OF NOVÁ BAŇA, ŠTÁL" AREA}

\author{
BC. LENKA ŠUHAJDOVÁ \\ DOC. ING. JANA JARÁBKOVÁ, PHD.
}

ING. MARIÁN HAMADA

\begin{abstract}
Katedra regionalistiky a rozvoja vidieka $\mid$ Department of Regional and Rural Development Fakulta európskych štúdii a regionálneho rozvoja Faculty of European Studies and Regional Develop. Slovenská polnohospodárska univerzita v Nitre Slovak University of Agriculture in Nitra $\bowtie \operatorname{Tr}$. A. Hlinku 2, 94976 Nitra, Slovak Republic

E-mail: jana.jarabkova@is.uniag.sk,marian.hamada@is.uniag.sk
\end{abstract}

\begin{abstract}
Anotácia
Cielom príspevku je poukázat' na významný potenciál a špecifiká rozptýleného osídlenia z hl'adiska rozvoja cestovného ruchu, analyzovat' a zhodnotit' súčasné využitie potenciálu vybraných objektov rozptýleného osidlenia v mikroregióne Nová Ban̆a v rámci Novobanskej štálovej oblasti. Rozptýlené osidlenie v skúmanej oblasti zostalo takmer v pôvodnej forme a podobe, avšak už dávno neplni svoju primárnu funkciu, ktorou je bývanie. Štruktúra štálového osídlenia nadobúda postupom času nový rozmer. Jednou z významných foriem domáceho cestovného ruchu je druhé bývanie a chalupárenie. Atraktívne okolie vybraných objektov vytvára predpoklady pre aktivity ako turistika a šport počas celého roku. Osobitne vhodné podmienky sú vytvorené pre rozvoj vidieckeho cestovného ruchu a agroturistiky. Príspevok ponúka aj odpovede na otázky Ako vnímajú miestni obyvatelia návštevníkov a osobitne chalupárov? Sú chalupári pre vybrané lokality prínosom alebo ich miestni obyvatelia vnímajú skôr negatívne?
\end{abstract}

Kl'účové slová

rozptýlené osidlenie, objekty individuálnej ekreácie, Novobanská štálová oblast, cestovný ruch

\section{Annotation}

The aim of this paper is to highlight the significant potential and specificities of scattered settlements in terms of tourism development, analyze and assess the current use of the potential of scattered settlements in the selected objects in the microregion Nová Ban̆a. Scattered settlements in the study area remained almost in its original form, but already does not fulfill its primary function of housing. Structure of "śtál" settlement acquires a new dimension over time. Significant form of domestic tourism is the second housing. Attractive surroundings of selected objects create conditions for activities such as hiking and sport during the whole year. Especially favorable conditions are created for the development of rural tourism and agrotourism. Article also provides answers to questions: How visitors are perceived by local residents? Are the visitors beneficial for selected sites or they are perceived rather negatively by local residents?

\section{Keywords}

dispersed settlement, objects of individual recreation, Nová Baňa „Štál“ area, tourism. 


\section{Úvod}

Rozptýlené osídlenie predstavuje svojbytný fenomén, na ktorý sa dá pozerat' z rôznych hl’adísk: sociálno-antropologického, demografického, urbanistického, historického, krajinno- ekologického, ale aj národopisného a viacerých d’alších. Zároveň ho možno vnímat' ako aktuálnu výzvu pre vedu a výskum, a to hlavne preto, že na jednej strane je zo všetkých sídelných typov najviac poznamenané depopulačnými tendenciami, zmenami pôvodného charakteru sídla až jeho zánikom, na druhej strane je typické svojimi relatívne dobre zakonzervovanými unikátnymi črtami (Huba - Ungerman, 1997). Z urbanistického hl'adiska reprezentuje rozptýlené osídlenie skupiny obytných a hospodárskych budov, od obcí viac alebo menej vzdialených, často i niekol'ko kilometrov a obývaných jednou, prípadne viacerými rol'níckymi rodinami. Jednotlivé objekty ležia v bezprostrednej blízkosti alebo uprostred obrábaných polí a lúk. Vzájomne sa líšia regionálne danými špecifikami ako sú napr. spôsob získania a obrábania novozískanej pôdy a pod. Základňou roztratených osád sú najmä podhoria a vrchoviny, ktorých výška sa pohybuje najčastejšie medzi 500 - 800 m Janšák (1967). V literatúre sa okrem termínu rozptýlené osídlenie často vyskytuje aj pojem kopaničiarske osídlenie. Vznik kopaničiarskych sídiel súvisel s vel'kým množstvom kopaničiarskej pôdy, ktorá bola z materských oblastí t’ažko prístupná. Táto pol'nohospodárska pôda predstavovala určitý potenciál pre obživu obyvatel'stva, najmä chudobnejšieho. Na vzdialených kopaniciach sa tak najskôr stavali sezónne obydlia a hospodárske stavby, ktoré sa neskôr stali základom trvalých kopaničiarskych sídiel. Ich vytváraním sa súčasne riešila otázka prel’udnenosti poddanských hospodárstiev v materských obciach (Petrovič, 2007). Kopaničiarske osídlenie je produktom najmladších kolonizačných vín na našom území a jeho genéza bola územne i časovo značne diferencovaná (Huba, 1990). Pôvod kopaničiarskeho osídlenia na Slovensku súvisí s tromi základnými kolonizačnými vlnami valašskou, horalskou (obe boli pastierske) a kopaničiarskou:

- valašská kolonizácia znamenala dosídlovanie horských oblastí severného a stredného Slovenska pastierskym obyvatel'stvom hlavne v 15. a 17. storočí. Valašská kolonizácia sa rozšírila v severných častiach Zemplína, Šariša, Spiša, Oravy a Trenčianskej stolice, na strednom Slovensku v časti Gemera a na Horehroní;

- horalská kolonizácia je mladšia, spadá do 17. - 18. storočia. Horali osídlili najmä územie na hornej Kysuci, hornej Orave a čast' severného Spiša;

- kopaničiarska kolonizácia znamenala vnútorné doosídl'ovanie horských a podhorských oblastí Slovenska domácim obyvatel'stvom v 16.-19.storočí. Kulminovala v 18. a v prvej polovici 19. storočia, ked' vznikla rozhodujúca väčšina kopaničiarskych sídiel. Touto kolonizáciou vznikali sídla v oblasti Kysúc a Oravy, Detvy, Malých a Bielych Karpát, Pohronského Inovca, Tribeča a Vtáčnika.

Podl'a Thurza (1997) rozptýlené osídlenie v súčasnosti na Slovensku tvorí celé oblasti. Pri pohl’ade z lietadla mnohé z nich pôsobia ako vel'ké zriedené sídelné aglomerácie. Každá z týchto oblastí má svoje neopakovatel'né špecifické črty. Jednou z takýchto oblastí sú aj Novobanské stále. Zaberajú územie od Topol’čianok cez Pohronský Inovec, Tribeč a Vtáčnik, medzi riekami Nitra a Hron, s presahom do Štiavnických vrchov (z hl'adiska historického v Tekovskej župe). K typickej l'udovej architektúre Novobanskej štálovej oblasti patrili blokové, prípadne zrubové domy so slamenou alebo šindl'ovou strechou. Bývali omazané a obielené, aj podpivničené a stavané do svahu. Po vysídlení nemeckého obyvatel'stva z Vel'kého Pola a Píly tu ešte mnoho rokov zostávali vyprázdnené a otvorené solídne stavané a dobre zachované domy, ktoré mali charakter l'udovej architektúry. Vo Vel'kej Lehote bolo ešte $\mathrm{v} 60$ tych rokoch zachovaných mnoho pôvodných objektov l'udovej architektúry so slamenými strechami, $\mathrm{v}$ tom čaše by ešte bolo bývalo vhodné $\mathrm{v}$ obci vyhlásit' pamiatkovú rezerváciu l'udovej architektúry.

Kopaničiarske osídlenie priamo v mikroregióne Nová Baňa vznikalo pôvodne v 14. storočí prevažne v spojitosti s baníctvom, uhliarstvom a pastierstvom, neskôr v dôsledku hospodársko-spoločenských zmien aj v súvislosti s pol’nohospodárstvom. Uhliarstvo a s ním súvisiace drevorubačstvo tvorilo zdroj obživy mnohých rodín z novobanských štálov a obcí Vel'ká a Malá Lehota. Životná úroveň rodín 
uhliarov bola nízka, odmeňovaní boli skromne, podl’a počtu smien a počtu zhotovených milierov. Pri tejto namáhavej a nebezpečnej práci pomáhali nezriedka aj ženy a deti.

Termín ,štále“ spája Stránska (1966) s obdobím prist’ahovalectva nemeckého obyvatel'stva na stredné Slovensko, v období rozvoja baníctva v 14. storočí. Nemeckí pristahovalci svoje chotárne, sezónne sídla volali „stande“, a aj slovenské „štále“ boli spočiatku iba sezónnym osídlením, s obydliami a hospodárskymi budovami, ktoré slúžili na letné ale aj zimné ustajnenie dobytka. V prípade Novej Bane a susedných Lehôt sa však už v druhej polovici 14. storočia väčšina týchto sezónnych sídiel mení na trvalé sídla. Základné údaje o postupnom vývoji osídlenia Novobanskej štálovej oblasti sú uvedené v Tabul'ke 1.

Tabul'ka 1: Základné údaje o osídlení Novobanskej štálovej oblasti

\begin{tabular}{|l|c|c|c|c|c|c|c|}
\hline & $\begin{array}{l}\text { Počet } \\
\text { obyv. }\end{array}$ & $\begin{array}{l}\text { Hustota } \\
\text { obyv. } \\
\text { (na km }^{2} \text { ) }\end{array}$ & $\begin{array}{l}\text { Počet obyv. } \\
\text { v centrách } \\
\text { obcí }\end{array}$ & $\begin{array}{l}\text { Počet } \\
\text { štálov }\end{array}$ & $\begin{array}{l}\text { Počet } \\
\text { obyv. } \\
\text { štáloch }\end{array}$ & $\begin{array}{l}\text { Podiel obyv. } \\
\text { vontrách } \\
\text { vobí (\%) }\end{array}$ & $\begin{array}{l}\text { Podiel } \\
\text { obyv. } \\
\text { śtaloch(\%) }\end{array}$ \\
\hline $\mathbf{1 . 3 . 1 9 6 6}$ & 20846 & 66,4 & 12755 & 174 & 8091 & 61,2 & 39 \\
\hline $\mathbf{3 0 . 6 . 2 0 0 6}$ & 18442 & 58,8 & 16123 & 169 & 2357 & 87,2 & 13 \\
\hline Zmena(v \%) & $-11,53$ & $-11,53$ & 26,41 & -5 & $-70,87$ & 42,48 & $-67,01$ \\
\hline
\end{tabular}

Zdroj: Vlastné spracovanie podl'a Enviromagazín, roč. 9, 2007, č. 3.

Z údajov možno identifikovat' nepatrný pokles štálov (v porovnaní s rokom 1961 sa počet štálov v roku 2006 znížil iba o 5 t.j. zo 174 na 169). Uvedený pokles však nesúvisí s ich úbytkom resp. zánikom, ale skôr postupným spájaním objektov v niektorých oblastiach. Zaujímavý je však razantný pokles obyvatel'ov v štálových oblastiach. Za obdobie 40-tich rokov sa znízil počet obyvatel'ov v štáloch až o 70,87\%, pričom počet obyvatel'ov v centrách obcí vzrástol o 42,48\%. V súčasnosti sú viaceré štále neobývané alebo využívané príležitostne - sezónne, pričom trend vysídl'ovania štálových oblastí bude pravdepodobne narastat' a dá sa predpokladat', že v blízkej budúcnosti sa väčšina oblastí rozptýleného osídlenia transformuje na rekreačné oblasti.

\section{Ciel’ a metódy práce}

Ciel’om príspevku je analyzovat' a zhodnotit' súčasné využitie potenciálu vybraných objektov rozptýleného osídlenia v mikroregióne Nová Baňa v rámci Novobanskej štálovej oblasti. V rámci analýzy sme sa koncentrovali na objekty individuálnej rekreácie, ktoré sú zaradené do kategórie neobývaných objektov. Detailnejšie sme analyzovali pät' objektov nachádzajúcich sa v Novobanskej štálovej oblasti. Zaujímali sme sa hlavne o účel využívania objektu a na základe toho sme definovali výmeru, lokalizáciu, pôvodné a súčasné využitie objektu. Územie mikroregiónu Nová Baňa patrí medzi menej známe a navštevované lokality $\mathrm{v}$ rámci Slovenska a preto sme sa zamerali na identifikáciu súčasných návštevníkov územia a ich motívy pobytu. Údaje o štruktúre návštevníkov mikroregiónu Nová Baňa sme získali prostredníctvom dotazníkového prieskumu realizovaného vo vybraných zariadeniach cestovného ruchu v mikroregióne Nová Baňa v období marec - apríl 2013. Vzájomné vzt'ahy medzi pôvodným obyvatel'stvom trvalo obývajúcim oblast' rozptýleného osídlenia a návštevníkmi tohto územia sme zist'ovali prostredníctvom štandardizovaného rozhovoru. Ciel'om rozhovoru bolo identifikovat' vzt’ahy medzi "novousadlíkmi" a "starousadlíkmi" v analyzovanom území, postoje obyvatel'ov k chalupárom a turistom, ale aj vplyv "novousadlíkov" a turistov na komunitný život na danom území.

\section{Prehl'ad súčasného stavu rozptýleného osídlenia v mikroregióne Nová Baňa}

Rozptýlené osídlenie v skúmanej oblasti ostalo zhruba v pôvodnej forme a podobe, avšak už neplní len svoju primárnu funkciu - bývanie. Niekol'ko faktorov ako zlá dopravná infraštruktúra, nedostatok pracovných príležitostí resp. nedostatočná občianska vybavenost', zmena životného štýlu obyvatel'ov, skoro úplné vymiznutie hospodársko-výrobnej funkcie, spôsobili a aj spôsobujú odliv obyvatel'ov 
a postupné vymieranie tejto etnograficky bohatej krajiny. Na „štáloch“ zostávajú prevažne len starší obyvatelia, pričom mladšia generácia odchádza bud’ do centier najbližších miest (Nová Baňa, Zlaté Moravce, Žarnovica, Žiar nad Hronom), alebo úplne odchádza z regiónu.

$\mathrm{Na}$ druhej strane priaznivá lokalizácia v turisticky atraktívnej nenarušenej krajine, v mozaike lúk, pasienkov a lesov spôsobuje nárast krátkodobej rekreácie a následne zmenu domového fondu na chaty a chalupy. Chalupárstvo je osobitá forma cestovného ruchu, ktorá sa v danej oblasti rozvíja už od 90tych rokov minulého storočia. Maximálnu intenzitu však nadobúda až v posledných rokoch. Tento jav sa dá pozorovat' na množstve trvalo neobývaných domov, ktoré z vel'kej časti slúžia ako chaty (tabul'ka 2).

Tabul'ka 2: Stav domového fondu rozptýleného osídlenia v roku 2012

\begin{tabular}{|c|c|c|c|c|c|}
\hline Obec/čast' mesta & Počet obyv. & $\begin{array}{c}\text { Neobývané/opustené } \\
\text { domy }\end{array}$ & Obývané domy & Chaty & Spolu \\
\hline Novobanské Štále & 952 & 36 & 262 & 94 & 392 \\
\hline Malá Lehota & 923 & 96 & 334 & 120 & 550 \\
\hline Vel'ká Lehota & 1166 & 48 & 358 & 120 & 526 \\
\hline Mikroregión & $\mathbf{3 ~ 0 4 1}$ & $\mathbf{1 8 0}$ & $\mathbf{9 5 4}$ & $\mathbf{3 3 4}$ & $\mathbf{1 4 6 8}$ \\
\hline
\end{tabular}

Zdroj: Interné materiály - Obecný úrad Vel'ká Lehota, Obecný úrad Malá Lehota, Mestský úrad Nová Baña, vlastné spracovanie

Rozptýlené osídlenie v obci Vel'ká Lehota pozostáva z 15 štálov, ktoré tvoria ucelenú čast' obce a dve osady Čikág a Inovec, vzdialené od centra obce 1,5 až $2 \mathrm{~km}$. Názvy štálov boli odvodené od priezviska obyvatel’ov alebo polohy štálu. Niektoré pôvodné názvy štálov sa použivajú dosial' napr. Šmondrkovci, Burovci, Gábrišovci, Dolní Garajovci, Cudenice, Pirte, Vaškovci, Zduchovci, Tutajovci, Mánikovci, Mihálovci, Chujacovci, Hudcovci a Viglášs. V katastri obce Malá Lehota sa nachádza 17 štálov. Jednotlivé štále spája $25 \mathrm{~km}$ miestnych komunikácií. Osamelé skupinky domov a časti štálov sú pomenované prevažne podl'a ich majitel’ov. Z 19. stor. sú známe štále - Blaska, Debnár, Domček, Hubač, Hucovcy (Hucócy), Hudec, Jazvinsky, Kopanica, Pacalay, Paulov, Petlus, Rajnoha, Smihňár, Šajba, Toma, Udička, Zimmermann (neskôr Závoz). V súčasnosti možno v Male Lehote nájst' štále, ktoré si zachovali svoj pôvodný názov alebo $\mathrm{v}$ mnohých názvoch možno identifikovat' pôvodných majitel'ov -Adamcov štál, Barancov štál, Debnárov štál, Dolná Šajba, Domčekov štál, Horná Šajba, Hubačov štál, Hudcov štál, Kopanica, Pacalajov štál, Pavlov štál, Rajnohov štál, Skálie, Tomov štál, Udičkov štál, Zimmermanov štál a Blaškov štál. Blaškov štál je považovaný za centrum. Podobne, väčšina názvov samôt, skupín domov novobanských štálov je odvodená od osobných mien pôvodných alebo neskorších majitel'ov príponou, napr. Bartošovci, Ištvánikovci, Feriancovci, Osúchovci, Lietajovci a pod.

Vybrané objekty rozptýleného osídlenia sú lokalizované v oblasti Novobanských štálov a v minulosti boli trvale obývané. V súčasnosti štyri z nich (Štálik, Bexápel, Sedliacky dvor na Kňazových lúkach a Banícky domček) slúžia pre účely individuálnej rekreácie a jeden objekt (Horský ranč) sa využíva ako zariadenie poskytujúce služby agroturistiky (tabul'ka 3 ).

Atraktívne okolie vybraných objektov vytvára predpoklady pre turistiku a šport počas celého roku. Osobitne vhodné podmienky sú vytvorené pre rozvoj vidieckeho cestovného ruchu a agroturistiky. Táto forma cestovného ruchu je spojená $\mathrm{s}$ náležitou rekreačno-športovou vybavenost'ou a možnost’ou poskytnutia regeneračno - rekondičných a zdravotníckych služieb. Cestovný ruch v mikroregióne je ovplyvňovaný prevádzkou rekreačného areálu Tajch. Areál poskytuje možnost' kúpania $\mathrm{s}$ možnost'ou ubytovania sa $\mathrm{v}$ stanovom tábore, prípadne $\mathrm{v}$ chatovej osade $\mathrm{v}$ súkromí. Rekreačný areál je $\mathrm{v}$ súčasnom období prevádzkovaný počas letnej sezóny, kedy sa $\mathrm{v}$ areáli konajú tradičné športové a kultúrne podujatia.

Územie mikroregiónu Nová Baňa je vhodné na rozvoj pešej turistiky, cykloturistiky, bežecké a zjazdové lyžovanie, jazdu na koňoch, rybolov, pol'ovníctvo, skalolezectvo a iné aktivity. Poskytovanie 
služieb týchto aktivít závisí od záujmu návštevníkov a možností jednotlivých zariadení cestovného ruchu.

V oblastiach Vel'kej a Malej Lehoty sú vybudované ly̌̆iarske vleky, upravené zjazdové trate, lyžiarske bežecké trate v dížke 21 a $22 \mathrm{~km}$, svoje služby poskytuje aj ski servis.

Pre turistov je k dispozícii niekol'ko značkovaných turistických trás a náučný chodník Vojšín. Trasa chodníka vedie prevažne lesným prostredím, prekonáva výškový rozdiel $350 \mathrm{~m}$ a jeho dížka je 10.5 $\mathrm{km}$. Má zriadených osem zastávok, ktoré informujú návštevníkov o faune a flóre miestnej lokality.

Prostredie Novej Bane a okolia poskytuje vel'mi dobré podmienky pre cykloturistiku aj vd’aka novovybudovanému cyklochodníku okolo Tajchu s dížkou cca $850 \mathrm{~m}$. V neposlednom rade poskytuje možnosti aj pre jazdenie na koni, ktoré ponúka niekol'ko chovatel'ov koní.

Z mikroregiónu je možné podniknút' výlety autom alebo na bicykli napríklad do kaštiela $\mathrm{v}$ Topolčiankach, na zrúcaniny hradov Revište a Šášov, do termálneho kúpaliska vo Vyhniach alebo do starobylej Banskej Štiavnice, či na turisticky atraktívne štiavnické jazerá.

Z dotazníkového prieskumu realizovaného $\mathrm{v}$ prevádzkach ubytovacích zariadení mikroregiónu Nová Baňa vyplynulo, že najpočetnejšiu návštevníkov analyzovaného územia tvorí kategória vo veku od 2645 rokov, naopak územie najmenej navštevujú turisti - seniori vo veku viac ako 65 rokov. Najčastejšie prichádzajú návštevníci z Bratislavského kraja (36\% všetkých návštevníkov mikroregiónu). Mnohí návštevníci prichádzajú aj z Banskobystrického kraja (25\%) a Nitrianskeho kraja (19\%). Výsledky prieskumu ukázali, že $86 \%$ všetkých návštevníkov mikroregiónu Nová Baňa je práve zo Slovenska. Približne 14\% návštevníkov prichádza zo zahraničia. Z hl'adiska krajiny domicilu sú to predovšetkým návštevníci z Českej republiky (7\%), Pol'ska (2\%) a Mad’arska (1\%). Zaujímavé je, že až 4\% všetkých návštevníkov tvoria Holand’ania, čo súvisí aj s vlastníctvom objektov v okolí Novej Bane a hlavne v jej odl'ahlých častiach, resp. v častiach s rozptýleným osídlením. $Z$ hl'adiska záujmov návštevníkov prevažujú „športovo založení účastníci cestovného ruchu“, ktorí tvoria $21 \%$ všetkých návštevníkov. Ďalšími najviac zastúpenými skupinami sú „milovníci prírody“ (17\%) a „rodiny s det’mi“ (12\%). V skupine „iné“ (10\%) respondenti uviedli kategórie ako hubári, cestovatelia a turisti. Medzi jednotlivými skupinami návštevníkov sa objavili aj „,hostia s diétou“ (2\%) alebo „telesne a zdravotne postihnutí účastníci cestovného ruchu“ (5\%), ktorí patria podl'a Timčáka (2009) tiež k cielovej skupine pre vidiecky cestovný ruch.

Využívanie objektov individuálnej rekreácie sa $\mathrm{v}$ mikroregióne Nová Baňa často spája $\mathrm{s}$ chalupárením. Návštevníci pritom prichádzajú do kontaktu s miestnymi obyvatel'mi opakovane počas pobytov, ktoré realizujú viackrát v priebehu roka. Atmosféru ciel'ového miesta dotvára aj správanie a pohostinnost' miestnych obyvatel'ov. Ako vnímajú miestni obyvatelia návštevníkov a osobitne chalupárov? Pri rozhovoroch s obyvatel'mi vybraných lokalít rozptýleného osídlenia sme sa dozvedeli, že do kontaktu s chatármi, chalupármi a turistami prichádzajú pomerne často. „V lete aj raz za týždeň. Niekedy si niečo požičajú. Alebo chcú pri nás parkovat'. Prírodné jazero Tajch je vo vel'kej miere navštevované či už domácimi, ale aj l'ud’mi z blizkeho i širšieho okolia. No ja tu stretávam l’udí, ktorí sa sem opakovane vracajú už dlhé roky a sú to l'udia aj z Českej republiky. Jazyková bariéra $v$ podstate neexistuje, takže sa s nimi dá rozprávat' a spomínat' aj na ,staré časy“. Ludia, ktori tu majú svoje súkromné chaty a chalupy, tak ich navštevujú pomerne často počas celého roka. No sú tu aj firemné chaty, ktoré sa využivajú hlavne v letnej sezóne a to ako pre svojich zamestnancov, ale aj pre ich rodinných príslušnikov. V areáli rekreačnej oblasti na nachádza novovybudovaný amfiteáter, ktorý je v lete často využivaný na rôzne spoločenské akcie, či už pre školopovinné deti, pre mládež, ale aj pre občanov seniorov. "(obyvatel' rekreačnej oblasti Tajch). Pri týchto spomínaných akciách sa často stretávajú s turistami, chatármi a chalupármi, ktorí si pochval'ujú služby, dobré kultúrno-spoločenské akcie, ale hlavne okolitú krásnu prírodu, vhodnú na turistiku, cykloturistiku, rybolov a hubárčenie.

V okolí Vel'kej a Malej Lehoty je vybudovaná rekreačná oblast' Drozdovo, ktorá je v prevádzke hlavne počas zimnej sezóny, kde si môžu návštevníci naplno vychutnávat' dovolenku na lyžiarskom 
svahu. Okrem Drozdova máme v regióne lyžiarske strediská Hubačov a Vojšín. Do tejto lokality prichádzajú l’udia či už v letnom alebo v zimnom období.

„Stretávam sa s rôznymi vekovými kategóriami chatárov a turistov. Od staršich manželských párov, ktoré prišli hl'adat' pokoj a prechádzky prírodou až po mladých l'udi, ktori si prišli uživat' letné prázdniny, zabávat' sa a opekat'. V zimnom obdobi ich zasa lákajú lyžiarske vleky a bežkárske trate. Intenzita styku s chatármi je teda pomerne vel'ká takmer počas celého roka. “(obyvatel' Vel'kej Lehoty)

V rozhovoroch s obyvatel'mi územia sme sa zamerali aj na vzt’ahy medzi starousadlíkmi (pôvodnými obyvatel'mi) a chalupármi, turistami, ktorých mnohí chápu ako novousadlíkov. Stretli sme sa $\mathrm{s}$ viacerými názormi, niektorí hodnotia vzt’ahy pozitívne, iní naopak negatívne. „Vzt’ahy medzi novousadlikmi a starousadlikmi by som mohol charakterizovat' ako v celku dobré. Je to hlavne z toho dôvodu, že novousadlíci sú často l'udia, ktorí tu majú svoje korene a vracajú sa do rodiska svojich predkov. Sú to l'udia, ktorí si často renovujú staršie domy po svojich rodičoch, starých rodičoch alebo pribuzných a známych. Sú aj takí, čo si stavajú chaty a chalupy... aj nové... alebo starši l'udia, ktorí sem prídu z mesta prežit' jeseñ svojho života. "(dôchodca z Malej Lehoty)

Pre väčšinu l’udí z mesta je chalupa miestom, kde zažívajú súzvuk s prírodou. Mnohí sa s chut’ou púštajú do rekonštrukcie a aj možno vd'aka tomu ich život nabral zo dňa na deň nový smer. Prácou okolo domu na čerstvom vzduchu si kompenzujú sedavé zamestnanie a postupne si vytvárajú prostredie, v ktorom zabudnú na všetky starosti. Miesto v hlbokom lese, oddelené od zvyšku sveta, však ponúka aj mnoho d’alších lákadiel, ktorým sa t’ažko odoláva. Nielen húb a lesných plodov je tu ako maku, ale ani stretnút' na prechádzke srnku tu nie je žiadna rarita. Jeden z chalupárov nám sám prezradil, že „mat' dobré susedské vzt'ahy s miestnymi obyvatel'mi je tu, na samote, na nezaplatenie“. Miestni mu počas jeho neprítomnosti z času na čas skontrolujú chalupu, či je všetko v poriadku a on im bezvýhradne dôveruje. „Pre l’udí z mesta je totiž divočina nielen oddychovým miestom, ale aj miestom, kde vznikajú priatel'stvá na celý život.“

Tak ako všetko, aj vzt'ahy medzi l'ud'mi záležia hlavne od povahy konkrétnych l'udí a konkrétnych miest. Môžeme konštatovat', že vzt'ahy medzi spomínanými skupinami sú pomerne dobré a dokonca si myslíme, že sú založené na tolerancii a spolupráci. Mnohí novousadlíci sa pokojne zaradili do komunity tunajších obyvatel'ov a snažia sa vychádzat's okolím. Novousadlíci predstavujú niečo nové, určité zmeny a často si neuvedomujú ako majú veci zaužívané starousadlíci a potom vznikajú konflikty, kedy nerešpektujú jeden druhého.

„Tu na Štáloch je už dnes v podstate viac chalupárov ako pôvodných obyvatelov, a vztahy s nimi neboli vždy príjemné. Niekedy mám pocit, akoby sme my, pôvodni obyvatelia, boli zo strany niektorých chalupárov vnímaní ako zaostali domorodci, ktorí nepoznajú ani telefón, či internet. A na druhej strane ani nemajú záujem nadväzovat' bližšie vzt'ahy. Ale v podstate, ja už som si na to zvykol. No musím podotknút, že nie všetci sú rovnaki, naozaj sú tu aj milí chalupári, či novousadlíci, ktorí tu bývajú len krátko, ale pomerne rýchlo sa prispôsobili životu na vidieku. "(obyvatel' Novobanských štálov)

Ked’ prichádza niečo nové, prináša to isté zmeny - narušenie svojho zaužívaného spôsobu. Je na každom človeku, ako sa postaví $\mathrm{k}$ danej situácií. To isté platí aj medzi novousadlíkmi a starousadlíkmi. Myslíme si, že najlepší spôsob je podat' pomocnú ruku novousadlíkom, pomôct' im zorientovat' sa v prostredí, ukázat' im výhody a krásy prostredia a úplne vypustit' nepríjemné situácie ako narušenie vzt'ahov, nezhody a podobne. Najlepší spôsob je zrušit' priepast' medzi starousadlíkmi a novousadlíkmi, tým že sa adaptujú do prostredia a budú si rovnocenní. Sú chalupári pre vybrané lokality prínosom alebo ich miestni obyvatelia vnímajú skôr negatívne? Návšteva turistov, chatárov má pozitívny prínos a vplyv z viacerých hl'adísk. $Z$ ekonomického hl'adiska - využívajú služby (ubytovania a stravovanie), ktoré poskytujúmiestni podnikatelia, prezentujú skúsenosti $\mathrm{s}$ pobytu v mikroregióne $\mathrm{v}$ miestne, kde žijú, zúčastňujú sa kultúrnych, spoločenských a športových podujatí počas pobytu $\mathrm{v}$ mikroregióne. 
Obyvatelia mikroregiónu vnímajú pozitívne najmä lokality s koncentrovanou ponukou služieb cestovného ruchu ako napr. rekreačnú oblast' Tajch. „Naša oblast' je známa svojou krásnou prírodou ktorá ponúka možnost' rekreácie hlavne v letných mesiacoch vd'aka jazeru Tajch - známa ako pol'ovnicka, rybárska oblast' či skvelé miesto turistiky ako takej. " (poslankyña mesta Nová Baňa).

V snahe prilákat' turistov a pomôct' vytvorit' nové pracovné miesta pre tunajších obyvatel'ov boli vybudované dva komplexy ktoré poskytujú cudzincom ubytovacie a stravovacie služby. „Jednoznačne by som povedal že vplyv chatárov a turistov je prínosom pre mesto a okolie. Ako príklad môžem uviest' zrenovovanú vel'kú firemnú chatu, ktorá bola v dost' zlom stave a dnes je z nej krásny penzión. Náš rodák, povolaním architekt (považujeme ho za novousadlika), chatu odkúpil, zrenovoval, rozširil a poskytuje tu služby na vel'mi slušnej úrovni. Jedná sa o ubytovanie, stravovanie, zabezpečovanie spoločenských akcii ako sú firemné porady, svadby, promócie a mnohé rodinné akcie. Ďalšim prikladom je novovybudovaný kemping. Podnikatel', ktorý si tu kúpil chalupu, tu vybudovalkemping a stále ho rozširuje. " (obyvatel' rekreačnej oblasti Tajch). Prevádzkovatel' v areáli poskytuje ubytovanie v bungalovoch, karavanoch alebo v stanoch a stravovanie. V letnej sezóne tu usporadúva rôzne akcie $\mathrm{v}$ spolupráci s vedením mesta alebo $\mathrm{s}$ rôznymi miestnymi podnikatel'mi. Populárne sú najmä motoristické zrazy, vrátane zrazu veteránov. V spolupráci s mestom usporadúva festival rôznych amatérskych skupín, kde sa môžu verejne prezentovat' mladí a nádejní umelci. „D̃alším prínosom spomínaného podnikatela je aj podnet na vybudovanie novej čističky a pripojky vody, ktorú využivajú nielen turisti v kempe, ale aj samotni obyvatelia danej lokality. "(obyvatel" rekreačnej oblasti Tajch). Výstavba spomínaných zariadení bola miestnymi obyvatel'mi skutočne vítaná. Poskytla obyvatel'om pracovné príležitosti či už počas výstavby, alebo počas samotnej prevádzky.

„Po pár rokoch sa rozhodlo investovat práve do tejto oblasti i mesto a začalo sa s výstavbou amfiteátra a dráhy pre korčuliarov, cyklistov či bežcov, ktorá vedie okolo celého jazera. " (poslanec mesta Nová Ban̆a)

Od tejto doby sa mnohé zmenilo, rozšírenie možností ubytovania a intenzívnejšia propagácia prilákali do oblasti mikroregiónu viac turistov zo Slovenska ale i zahraničia. Vybudovaním infraštrukúry pre poskytovanie d'alších služieb sa však otvorili nové možnosti trávenia vol'ného času aj pre miestnych obyvatel'ov. Skvalitnili sa stravovacie služby a ponuka podujatí, ktoré sa v letných mesiacoch organizujú.

V oblastiach Vel'kej a Malej Lehoty vnímajú chalupárov a turistov podobne ako voblasti Novobanských štálov. „Z pohl'adu rozvoja obce vnímame chatárov pozitivne najmä preto, lebo sa po kúpe nehnutel'nosti sa snažia skrášlit' prostredie vokoli svojho bydliska a obnovit' kúpenú nehnutel'nost'. Zvyšuje sa návštevnost' obce a dostáva sa do širokého povedomia obyvatelov. Teraz sa kúsok od našej obce, v oblasti lyžiarskeho strediska Vojšin, buduje chalupárska oblast'. Myslím, že do budúcna nás to dost' ovplyvní... Bude to hlavne prínos pre obecnú kasu. " (starostka obce Vel'ká Lehota)

Obyvatelia obcí vnímajú prítomnost' chalupárov vich okolí ako možnost' privyrobit' si. „Prevádzkovatelia pohostinstiev a d'alši drobní živnostníci (napr. taxi služby) majú cez hlavnú sezónu vyššie tržby častokrát aj vd'aka chatárom. Chatári dajú vel'akrát zarobit tunajším obyvatel'om, ktorí im napília drevo, prípadne pri prestavbách chalúp im pomáhajú pri základných stavebných prácach. Spozoroval som, že chatári si váźia vidiek. Uprednostňujú ,aktívny odpočinok“, čím mám na mysli zvel'ad'ovanie svojho okolia (záhrada, stromy, skalky). “( obyvatel' Malej Lehoty)

Z estetického hladiska, musíme konštatovat', že vplyv chatárov a chalupárov je vel'kým plusom na rozvoj a chod danej oblasti a mesta. Vybudované nové chaty, či už súkromné alebo na rôzne podnikatel'ské aktivity ako je prenájom a pod. skrášlujú a vhodne dopínajú kolorit nášho územia, ale hlavne rozširujú možnosti podnikania v oblasti športu, cestovného ruchu a vol'nočasových aktivít. 
Z rozhovorov s miestnymi obyvatel'mi oblastí s rozptýlenám osídlením vyplynuli aj negatívne skúsenosti s návštevníkmi. Problémom, s ktorým sme sa stretli opakovane, je nadmerný hluk počas rôznych podujatí, ktoré sa organizujú v rekreačných oblastiach a s tým je spojené aj množstvo nahromadeného a porozhadzovaného odpadu v okolí rekreačných zariadení. „Musím spomenút aj isté negatíva, ktoré ovplyvňujú život obyvatelov v našej oblasti. Je to najmä v letnej sezóne, pri rôznych spoločenských akciách ako sú festivaly, koncerty a diskotéky. Je to vo vel'kej väčšine mládež, ktorá je nadmerne hlučná a narúša nočný klud. Po rôznych koncertoch a diskotékach ostáva tiež vel'ký neporiadok $v$ blizkom okoli a cestou smerom $k$ mestu. Je však pravda, že usporiadatelia sa snažia vždy $v$ čo najkratšom čase tento neporiadok odstránit', či už vlastnými prostriedkami, alebo v spolupráci s technickými službami mesta Nová Baña. Zvýšená doprava je s rozvojom turizmu samozrejmá, a to má za následok aj zvýšené znečistenie ovzdušia. Nizky počet parkovacích miest spôsobuje parkovanie áut na rôznych miestach, nie na to určených, ale aj na trávnatých plochách, čo má za následok aj znečistovanie a znehodnocovanie vody a prirody samej. "(senior žijúci v rekreačnej oblasti Tajch)

Ďalší problém, ktorý sme postrehli je nezodpovednost' chatárov, pochádzajúcich prevažne z mestského prostredia, ktorí si niekedy neuvedomujú následky svojho nezodpovedného správania. Problém súvisí so šetrným využívaním vody hlavne v suchých letných mesiacoch. „Ved’ oni si sem prídu len oddýchnut' na úkor našich nervov a pitnej vody, ktorou si poumývajú v horúcich letných mesiacoch svoje „,bavoráky“, popolievajú si svoje trávničky, prípadne si napustia pár kubikový bazén. "(obyvatel' Novobanských štálov) Ich nezodpovedné hospodárenie s vodou, na ktoré sú naučení $\mathrm{z}$ miest a bytov, kde je pri otočení kohútikom dostatok vody, vedie k tomu, že tunajší obyvatelia potom trpia ich správaním a nemajú dostatok vody ani na základné potreby, čo pokladáme za dost' závažný problém.

V obci Malá Lehota sme postrehli problém súvisiaci s rozrastajúcim sa počtom chalupárov a chatárov, ktorí narúšajú súkromie pôvodných obyvatel'ov, pričom sa postupne stráca aj pokoj vyžarujúci z vidieckeho prostredia. Môžeme konštatovat', že starousadlíci nie sú celkom spokojní s prítomnost'ou chatárov či chalupárov. „Samozrejme, predtým, ked’ sme tu nemali ešte do takej miery rozšírenú komunitu chatárov, bolo tu pokojnejšie, povedal by som, že nám chalupári vzali to krásne ticho, šepot vetra a spev vtákov, ktorý postupne vystriedali podgurážení, arogantni chalupári, ktorým je to, samozrejme jedno. Ďalej môžem k tomu povedat', že pred výstavbou domov, chalúp, či už rekreačných zariadení, ktoré sa realizujú v tejto oblasti, sme tu mali omnoho lepšie cestné komunikácie, ktoré sa po následnom rozbití nikto z dotyčných chalupárov nesnaži dat' do poriadku. "(obyvatel' Malej Lehoty)

V obci Vel'ká Lehota sú vzt'ahy miestnych obyvatel'ov a chalupárov realtívne pokojné a miestni vnímajú návštevníkov prevažne pozitívne. Negatívne vnímajú len zvýšenú frekvenciu dopravy počas zimnej sezóny, kedy prichádzajú návštevníci do oblastí lyžiarskych stredísk. „Chalupári nenarúšajú pokoj vobci. Len pri turistoch, hlavne vzimných mesiacoch, ked’ navštevujú ski centrum sme zaznamenali zvýšenú dopravu. Je v záujme obce aby sa postarala o pohodlie a poriadok vobci. Obec sa snaži opravovat' miestne komunikácie, starat' sa o čistotu v obci a zabezpečovat' pravidelný prísun vody (v našej obci je problém s vodovodom, preto je voda regulovaná). Negatívne skúsenosti máme hlavne s nesprávnym nakladaním s komunálnym odpadom, vznikajú zakázané skládky odpadu." (starostka Velkej Lehoty)

Vd’aka postojom a názorom obyvatel'stva žijúceho v oblastiach s rozptýleným osídlením sme sa mohli lepšie zorientovat' $\mathrm{v}$ niektorých otázkach týkajúcich sa života na vidieku, ale aj rôznych vzt’ahov chatárov/chalupárov a turistov $\mathrm{k}$ miestnym obyvatel'om. Vzt'ahy medzi obyvatel'mi a chatármi či turistami sú viac menej priatel'ské. Nezaznamenali sme vážnejšie konflikty, ktoré by vyplývali zo vzájomného spolunažívania, pretože väčšina chatárov sa začlenila do komunity tunajších obyvatel'ov. Mnohí z „,novousadlíkov“ však nemajú záujem nadväzovat' bližšie kontakty, takže vzt’ahy sú skôr neutrálne, čo je však lepšie, ako by mali vznikat' zbytočné konflikty. Je pravda, ak prichádza niečo nové, prináša to so sebou aj určité zmeny, a tak to je aj v prípade zmeny štruktúry objektov individuálnej rekreácie. 
Chalupári a turisti zohrávajú dôležitú úlohu aj z pohl'adu rozvoja územia. Predstavujú významný faktor rozvoja podnikatel'ských aktivít s vysokým stupňom pridanej hodnoty. Ekonomický potenciál je rozhodujúcim faktorom rozvojových možností územia a príležitost'ou pre zlepšenie životnej úrovne jeho obyvatel'stva. Mnohí z chalupárov investovali svoje finančné prostriedky práve do oblastí s rozptýleným osídlením. Vybudovali tu niekol'ko zariadení poskytujúcich služby pre cestovný ruch, a vd’aka nim poskytli pracovné príležitosti miestnym obyvatel'om. Regiónu pomáhajú aj využívaním stravovacích alebo ubytovacích služieb, zúčastňujú sa rôznych podujatí, ktoré sa v okolitých oblastiach organizujú, ale zároveň propagujú územie vo svojom regióne. Pozitívom je aj zmena domového fondu štálových oblastí na chaty a chalupy, čím sa zachováva pôvodná výstavba budov. Z negatívneho hl'adiska je vel'kým problémom nadmerný hluk počas letnej sezóny, kedy mnohí návštevníci organizovaných podujatí narúšajú nočný pokoj. Takisto problémom je aj zvýšená doprava a ničenie ciest. Nezodpovednost' niektorých chatárov vedie však aj k závažnejším problémom, ako napríklad nedostatok pitnej vody, ktorú míňajú na polievanie trávnikov, či napúšt’anie bazénov.

Historické krajinné štruktúry rozptýleného osídlenia sú vel'mi zranitel'né a podliehajú rôznym zmenám a narušeniu, preto je potrebné venovat' im zvýšenú pozornost' a hl'adat' riešenia na zachovanie špecifického osídlenia. Z hl’adiska postavenia a potrieb mikroregiónu Nová Baňa je dôležité, aby aspekty jeho rozvoja jednak vnútri a jednak vzhl'adom na potreby okolia boli vyvážené. Oblasti s rozptýleným osídlením majú všetky predpoklady na to, aby sa vyvíjali harmonicky, zhodnocovali svoj rozvojový potenciál a vytvárali tak podmienky pre trvalé zvyšovanie kvality života miestnych obyvatel'ov.

\section{Záver}

Novobanský region, osobitne oblasti s rozptýlením osídlením, patrí k zaujímavým, ale málo poznaným regiónom Slovenska. Jednou z možností, ako využit' jeho potenciál je rozvoj vidieckeho cestovného ruchu a agroturistiky (Otepka - Habán, 2007). Rozptýlené osídlenie tvorí vel’mi vzácnu súčast' krajiny a vd’aka jeho obmedzenému výskytu je atraktívnym územím pre rozvoj cestovného ruchu. Mala by sa mu venovat' zvýšená pozornost' a je potrebné hladat' riešenia na zachovanie historických krajinných štruktúr. Predpokladom úspešného zachovania územia je podporovat' individuálne formy cestovného ruchu a tým zabránit zániku niektorých oblastí rozptýleného osídlenia. Vhodným spôsobom je rozširovat' vznik objektov individuálnej rekreácie, resp. objektov poskytujúcich špecifické služby pre vidiecky cestovný ruch z neobývaných a nevyužívaných objektov (Šíp, 2007). Dôležitým aspektom je zabezpečenie kvalitných služieb pre uspokojovanie potrieb turistov v športovo-rekreačných zariadeniach, zachovanie tradičných zvyklostí a remesiel a zintenzívnenie propagácie a publicity regiónu čímmožno prispiet' $\mathrm{k}$ lepšej informovanosti o atraktivite územia s rozptýleným osídlením.

\section{Literatúra}

[1] HUBA, M. O perspektívach kopaničiarskeho osídlenia a kopaničiarskej krajiny na území Slovenskej republiky. Geografický časopis, 1990, roč. 42, 1990, č. 2, s.113-129.

[2] HUBA, M., UNGERMAN, J. Kopaničiarske osídlenie, životné prostredie a trvalo udržatel'ný spôsob existencie [online]. Životné prostredie, 1997, roč. 31, 1997, č. 2, [cit. 2013-01-11]. Dostupné na: <file:///D:/\%C5\%A0kola/Bakal\%C3\%A1rka/huba-kopanice-definicie.htm>.

[3] JANŠÁK, Š. O kopaničiarskom osídlení na Slovensku. Vlastivedný časopis, 1967, roč. 16, č.1, Bratislava, 1967. pp. 23-28.

[4] OTEPKA, P.- HABÁN, M. Vidiecky turizmus a agroturizmus. NOI, Nitra 2007. ISBN 978-8089088-52-2

[5] PETROVIČ, F. Originalita rozptýleného osídlenia na Slovensku. Enviromagazín, 2007, roč. 9, č. 3 , s. 24-25.

[6] STRÁNSKA, D. K otázce zvýšených staveb na Slovensku. Slovenský národopis, 1966, roč. 14, č. 1, s. 65-122. 
[7] ŠÍP, J. Hodnota území venkova pro rozvoj cestovního ruchu. In Kraft, S., Mičková, K., Rypl, J., Švec, P., Vančura, M. (eds) Česká geografie v evropském prostoru - Sborník z XXI. sjezdu ČGS, Jihočeská univerzita v Českých Budějovicích, Pedagogická fakulta, katedra geografie, 2007. s. 752-762, ISBN 978-80-7040-986-2

[8] THURZO, I. Dispersed Settlement - a Traditional Part of Our Countryside [online]. Životné prostredie, 1997, roč. 31, č. 2, [cit. 2013-01-15]. Dostupné na: $<$ file://D:/\%C5\%A0kola/Bakal\%C3\%A1rka/thurzo2-rozptylene\%20osidlenietradicna $\% 20$ sucast $\% 20$ nasho\%20vidieka.htm>.

[9] TIMČÁK, G.M. Cestovný ruch. Košice: Inštitút vzdelávania veterinárnych lekárov v Košiciach, 2009. 67 s. ISBN 978-80-89280-24-7

\section{Príloha}

Tab. 3: Pôvodné a súčasné využitie vybraných objektov rozptýleného osídlenia Novobanskej štálovej oblasti

\begin{tabular}{|c|c|c|}
\hline $\begin{array}{l}\text { Objekt } \\
\text { rozptýleného } \\
\text { osídlenia }\end{array}$ & Pôvodné využitie objektu & Súčasné využitie objektu \\
\hline Štálik & $\begin{array}{l}\text { Názov objektu „Štálik“ pochádza z nemeckého } \\
\text { slova "stall”- maštal'. Stavba bola pôvodne } \\
\text { postavená ako sezónna maštal' pre dobytok a } \\
\text { hospodárska budova na uskladnenie sena } \\
\text { a pol'nohospodárskeho náradia. Miestni gazdovia } \\
\text { stavali takéto stavby zvyčajne na vzdialených } \\
\text { lúkach a majetkoch.Stavba bola dokončená v roku } \\
1930 \text { (datované podla nápisu na krokve strechy). } \\
\text { Polovica budovy bola postavená z kameňa (maštal) } \\
\text { a polovica z dreva (senník). Strecha bola pokrytá } \\
\text { škridlou. Zaujímavost'ou je že stavba nakoniec } \\
\text { nikdy nebola využitá ako maštal'. Dôvod nie je } \\
\text { presne známy, ale pravdepodobne to súviselo s } \\
\text { tým, že hospodárstvo majitel'ov bolo od objektu } \\
\text { vzdialené približne } 150 \mathrm{~m} \text { a možno k tomu prispela } \\
\text { aj hospodárska kríza v 30-tych rokoch, vojnové } \\
\text { udalosti či následná kolektivizácia. }\end{array}$ & $\begin{array}{l}\text { Momentálne je objekt nevyuživaný z dôvodu } \\
\text { rekonštrukcie. Využíva sa len záhrada } \\
\text { a ovocný sad, pričom sa ani v budúcnosti } \\
\text { nepočíta s trvalým obývaním objektu. Pri } \\
\text { chalupe sa nachádza krásna záhrada, v ktorej } \\
\text { chce majitel' vybudovat' zastrešený altánok } \\
\text { s krbom a záhradným nábytkom. Majitel' } \\
\text { plánuje v budúcnosti využívat' objekt a jeho } \\
\text { pril'ahlé pozemky na rekreačné } \\
\text { účely a uvažuje aj o prenajímaní objektu } \\
\text { priatel'om a známym. }\end{array}$ \\
\hline Bexápel & $\begin{array}{l}\text { Stavba bola pôvodne postavená ako murovaný } \\
\text { rodinný dom s pril'ahlými stavebnými objektmi - } \\
\text { letná kuchyňa s drevárňou a maštal'. Bexápel } \\
\text { osídlila rodina, ktorá tam postavila } 4 \text { rodinné domy, } \\
\text { konkrétne na Hornom a na Dolnom Bexápli. } \\
\text { Pôvodní obyvatelia sa živili pol'nohospodárstvom, } \\
\text { chovom hovädzieho dobytka, pastierstvom, } \\
\text { ovocinárstvom, prácou v lesoch ako drevorubači, } \\
\text { neskôr rôznou prácou v meste Nová Baňa. } \\
\text { Vzhl'adom k zmeneným spoločenským } \\
\text { podmienkam a neprístupnosti na horskom teréne } \\
\text { došlo k opúšt'aniu Bexápla a pôvodní obyvatelia sa } \\
\text { st'ahovali do mesta za pohodlnejším bývaním } \\
\text { a prácou }\end{array}$ & 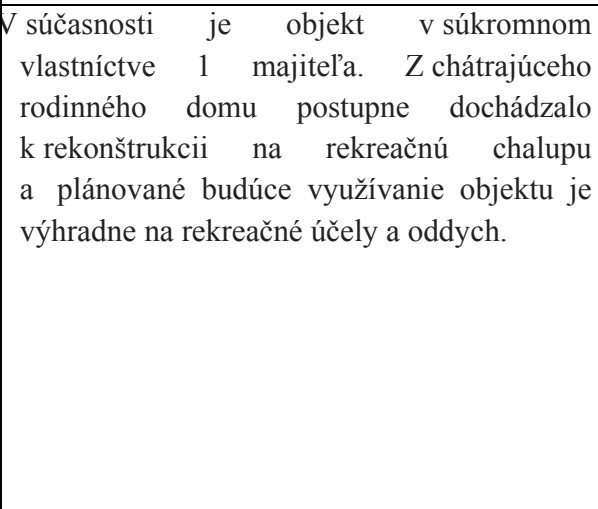 \\
\hline $\begin{array}{l}\text { Sedliacky dvor na } \\
\text { Kňazových } \\
\text { lúkach }\end{array}$ & $\begin{array}{l}\text { Pôvodná drevenica bola postavená v roku } 1886 \text {. } \\
\text { Bola to klasická malá drevenica z dubového dreva } \\
\text { a prikrytá drevenými šindl'ami. Majitelia boli } \\
\text { sedliaci, no napriek tomu že hospodárili, vyrábali } \\
\text { sa u nich mlynské kamene a materiál dovážali } \\
\text { z blízkeho kameňolomu. Zaujímavost'ou je, že } \\
\text { v rokoch } 1901 \text { a } 1902 \text { túto drevenicu navštívil } \\
\text { a pobudol v nej niekol'ko dní známy český } \\
\text { spisovatel' Jaroslav Hašek so svojím bratom. } \\
\text { Navštívili vtedajšieho majitel'a Štefana Volfa- } \\
\text { Kňazolúckeho, národovca, spisovatel'a a zberatel'a } \\
\text { piesní a povestí. V roku } 1942 \text { bola postavená väčšia }\end{array}$ & $\begin{array}{l}\text { V roku } 2009 \text { sa začala postupná renovácia } \\
\text { malej drevenice a pril'ahlej hospodárskej } \\
\text { budovy, ktorá pokračuje dosial'. Zachovali sa } \\
\text { rôzne predmety a písomnosti z obdobia, ked' } \\
\text { sa na tomto dvore žilo, pracovalo } \\
\text { a hospodárilo, a stali sa predmetom dnes už } \\
\text { existujúcej pamätnej izby. Táto pamätná izba } \\
\text { je venovaná hlavne životu a pôsobeniu } \\
\text { národovca Štefana Volfa - Kňazolúckeho. } \\
\text { V súčasnosti tvoria objekt štyri budovy, ktoré } \\
\text { slúžia na účely malého múzea. V drevenici je } \\
\text { už spomínaná pamätná izba. Súčast'ou }\end{array}$ \\
\hline
\end{tabular}




\begin{tabular}{|c|c|c|}
\hline & $\begin{array}{l}\text { hospodárska budova, ktorá prekryla aj starú } \\
\text { drevenicu. V roku } 1990 \text { pril'ahlé majetky aj s } \\
\text { budovami znárodnil štát. Až v roku } 2006 \text { odkúpil } \\
\text { majetky aj s pozostatkami budov súčasný majitel' } \\
\text { spolu so svojím otcom. }\end{array}$ & $\begin{array}{l}\text { expozície sú rôzne pracovné } \\
\text { pol'nohospodárske predmety, ktoré sú } \\
\text { vystavené v hospodárskej budove. V objekte } \\
\text { sa nachádzajú aj pozostatky mlynských } \\
\text { kameňov, ktoré vyrábali pôvodní majitelia. } \\
\text { Ďalšou budovou je stará kôlňa, v ktorej sa } \\
\text { nachádza sklad palivového dreva. Je to stará } \\
\text { budova, v dost' zlom stave. Vedl'a nej sa } \\
\text { nachádza prerobené malé stavanie. Je to už } \\
\text { novodobá stavba, ktorá je využívaná ako } \\
\text { rekreačná chalupa. Vzhladom na majetkové } \\
\text { pomery a na široko rozvetvenú rodinu má } \\
\text { objekt v súčasnosti } 26 \text { majitel'ov vrátane } \\
\text { štátu. }\end{array}$ \\
\hline Banícky domček & $\begin{array}{l}\text { Pôvodný objekt vybudovala rodina baníka. Objekt } \\
\text { bol stavaný do mierneho svahu na kamennej } \\
\text { podmurovke a bol podpivničený. Strecha objektu je } \\
\text { sedlová, v minulosti ju pokrýval šindel' } \\
\text { a v súčasnosti plech. Obývacia čast' pozostávala z } 2 \\
\text { izieb, komory a pitvora, ktorý bol delený na } \\
\text { kuchyňu. Súčast'ou zadnej časti objektu bola aj } \\
\text { stajňa, ktorá však bola zrútená. Potomkovia sa po } \\
\text { smrti pôvodného majitel'a rozpŕchli do okolitých } \\
\text { krajín za prácou a objekt zostal neobývaný. }\end{array}$ & $\begin{array}{l}\text { V roku } 2003 \text { odkúpil objekt súčasný majitel'. } \\
\text { Domček prešiel čiastočnou rekonštrukciou } \\
\text { a je využívaný ako rekreačná chalupa. Ako } \\
\text { nám prezradil majitel', na trvalé obývanie je } \\
\text { to príliš malé, ale na odreagovanie od } \\
\text { všetkých starostí a uponáhl'aného života je } \\
\text { toto prostredie pre mña a moju rodinu ako } \\
\text { stvorené“. Pozemok okolo objektu je malý } \\
\text { a majitel' na ňom vybudoval malé posedenie } \\
\text { s hojdačkou. }\end{array}$ \\
\hline Horský ranč & $\begin{array}{l}\text { Stavba bola postavená v roku } 1908 \text { ako rodinný } \\
\text { dom. Majitel' tu žil aj so svojou manželkou a } 3 \\
\text { det'mi. K objektu bola neskôr pristavaná aj } \\
\text { hospodárska budova. Majitelia sa živili chovom } \\
\text { oviec, kôz a dobytka, ale taktiež ovocinárstvom. } \\
\text { V priestoroch objektu sa každoročne organizovali } \\
\text { páračky, zábavy a dokonca fašiangy, kde sa stretli } \\
\text { l'udia z okolitých štálov. Po smrti maitel'a a jeho } \\
\text { manželky zostal dom opustený. Postupne chátral } \\
\text { a potomkovia sa rozhodli celý objekt aj } \\
\text { s pril'ahlými pozemkami predat. }\end{array}$ & $\begin{array}{l}\text { V roku } 2007 \text { objekt odkúpil súčasný majitel' } \\
\text { a rozhodol sa tu vybudovat’ krásny areál, } \\
\text { ktorý nazval „Horský ranč“. V roku } 2010 \\
\text { začal s rekonštrukciou a dnes je z objektu } \\
\text { vyttorené zariadenie poskytujúce všestranné } \\
\text { služby cestovného ruchu. } \\
\text { Zo starého domčeka vybudoval chatu, } \\
\text { v ktorej poskytuje ubytovanie. Nová chata } \\
\text { disponuje ubytovacou kapacitou } 9 \text { l'udí v } 3 \\
\text { izbách. Host'om je k dispozícii posedenie } \boldsymbol{s} \\
\text { ohniskom } \boldsymbol{i} \text { vínna pivnica. V areáli ranča } \\
\text { majitelia chovajú kone, psy a mačky. ranč } \\
\text { poskytuje množstvo možností pre trávenie } \\
\text { vol'ného času. Zariadenie ponúka niekol'ko } \\
\text { víkendových pobytov, kurzy sebaobrany, } \\
\text { workshop feng šuej, jogu alebo kung fu. } \\
\text { V blízkosti ranča sú možnosti hubárčenia } \\
\text { a lovu rýb. }\end{array}$ \\
\hline
\end{tabular}

Zdroj: Vlastné spracovanie.

Obr. 1 Objekt "Štálik"

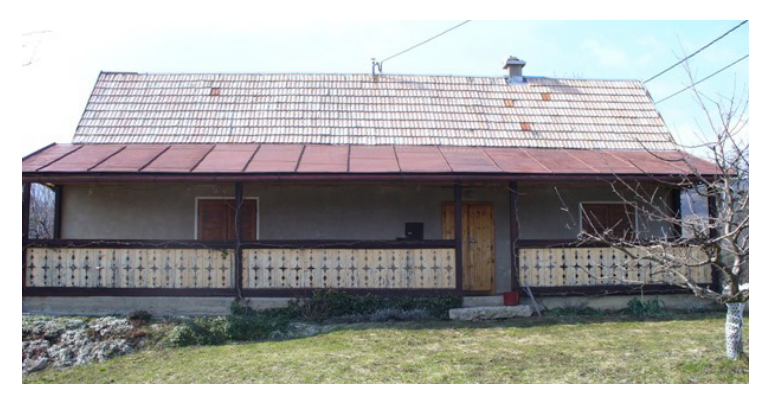

Obr. 2 Objekt "Bexápel”

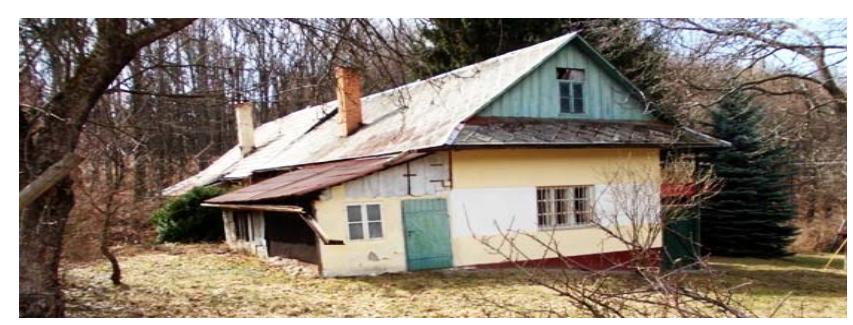

Zdroj: Archiv Bc. Lenky Šuhajdovej, 2013. 
Zdroj: Archív Bc. Lenky Šuhajdovej, 2013.

Obr. 3 Objekt "Sedliacky dvor"

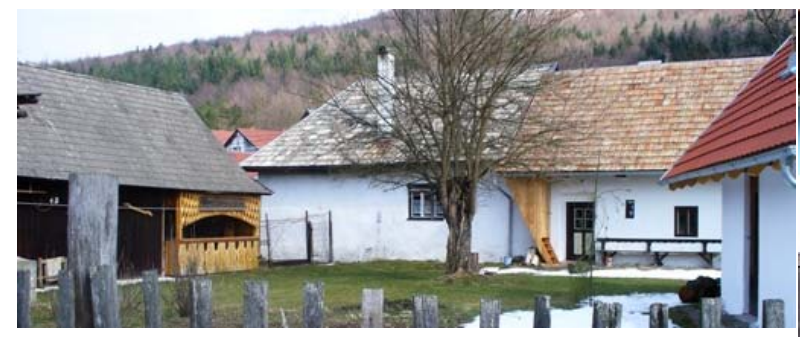

Zdroj: Archív majitel'a objektu, 2013.

Obr. 5 Objekt “Horský ranč”

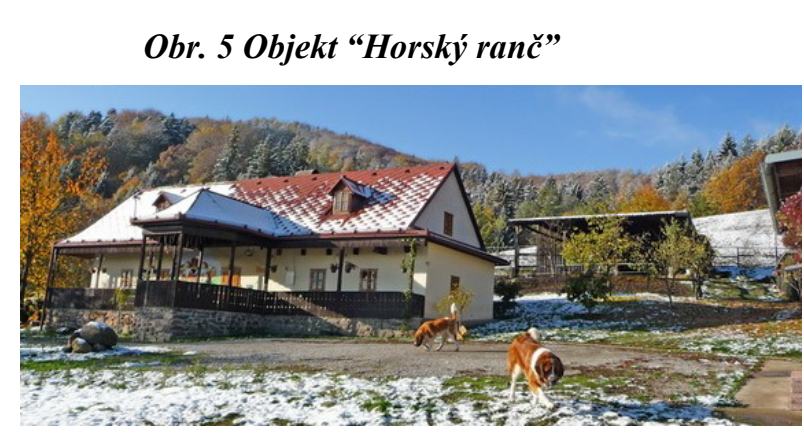

Zdroj: Archív majitel'a objektu, 2013.
Obr. 4 Objekt "Banícky domček"

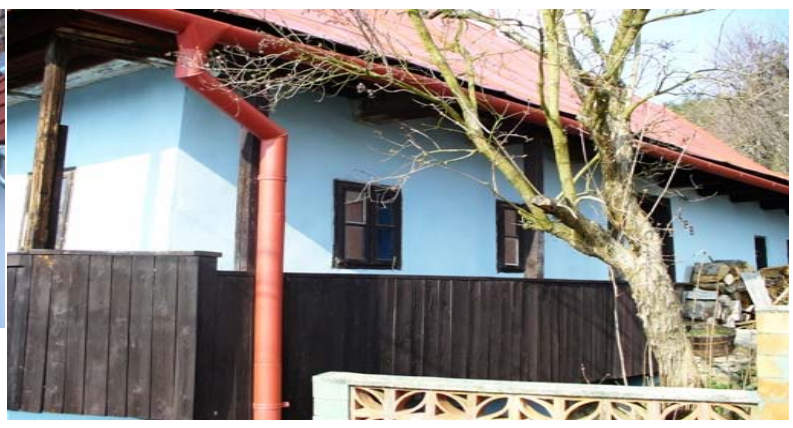

Zdroj: Archiv Bc. Lenky Šuhajdovej, 2013.

$$
\text { . }
$$

